\title{
THE DOG \\ AND
}

\section{HOW TO BREAK RIMI.}




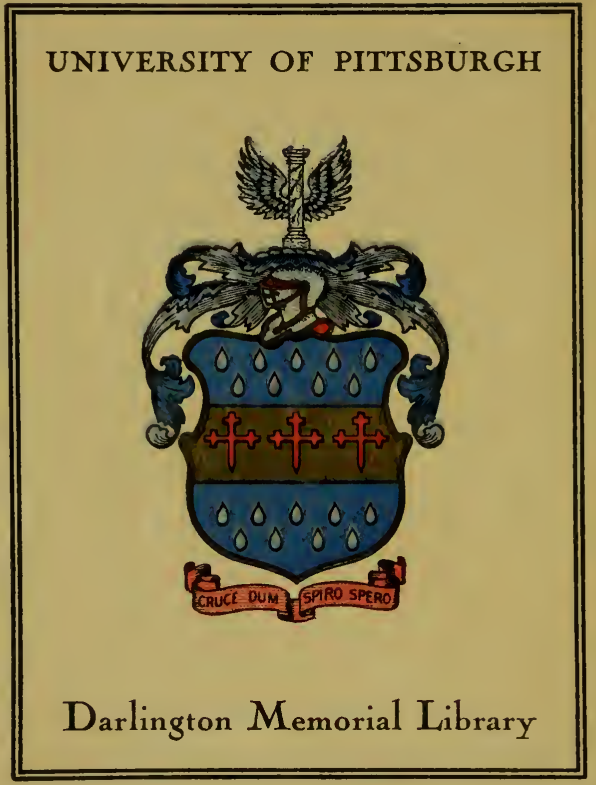




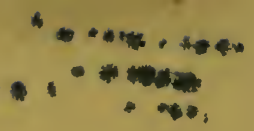

1628644 

(

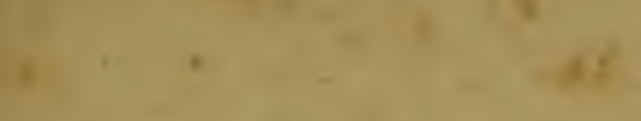

3

(1)

$*$

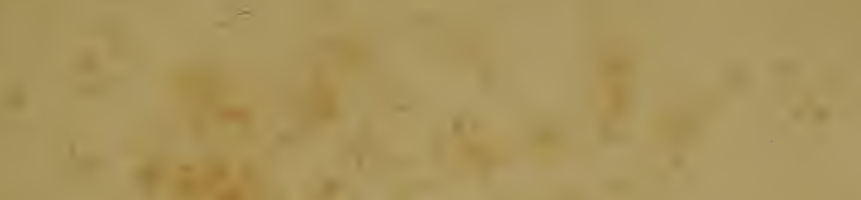

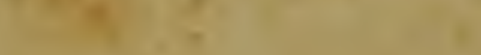

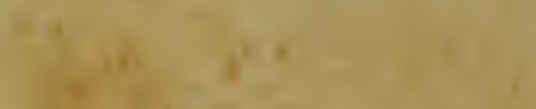

$$
\begin{aligned}
& \gamma=-
\end{aligned}
$$

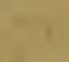

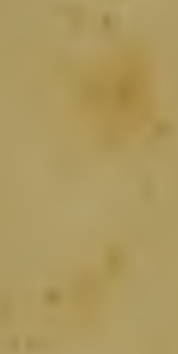

$=$

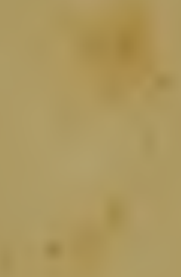

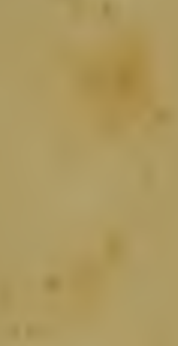

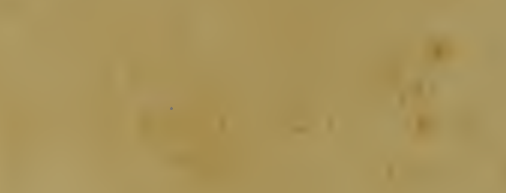

(n)

$-$

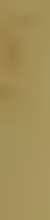

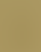
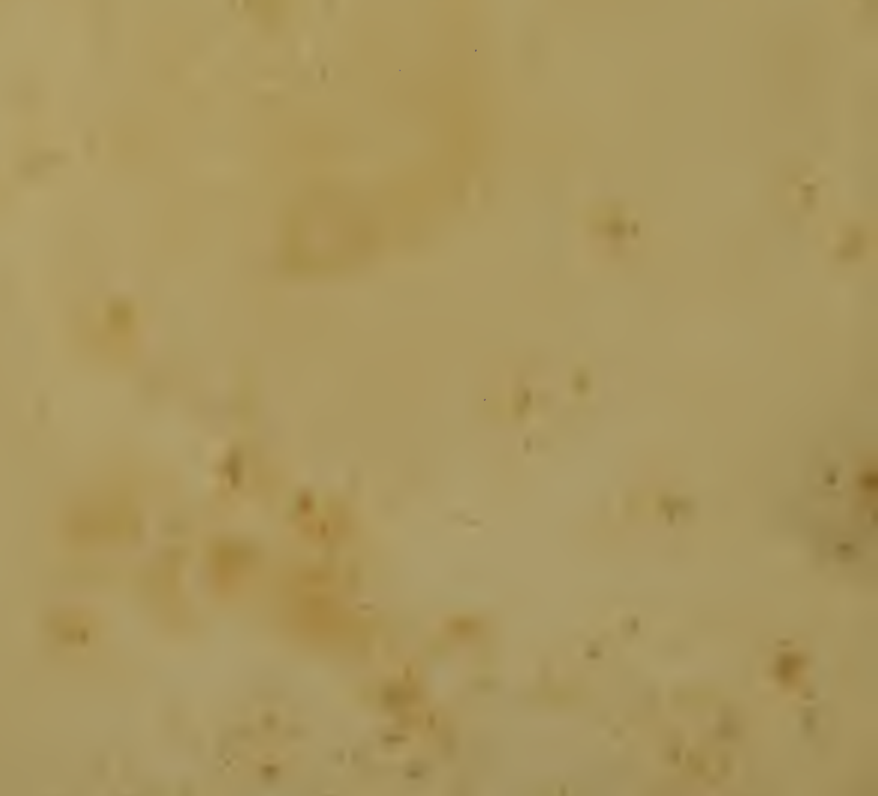


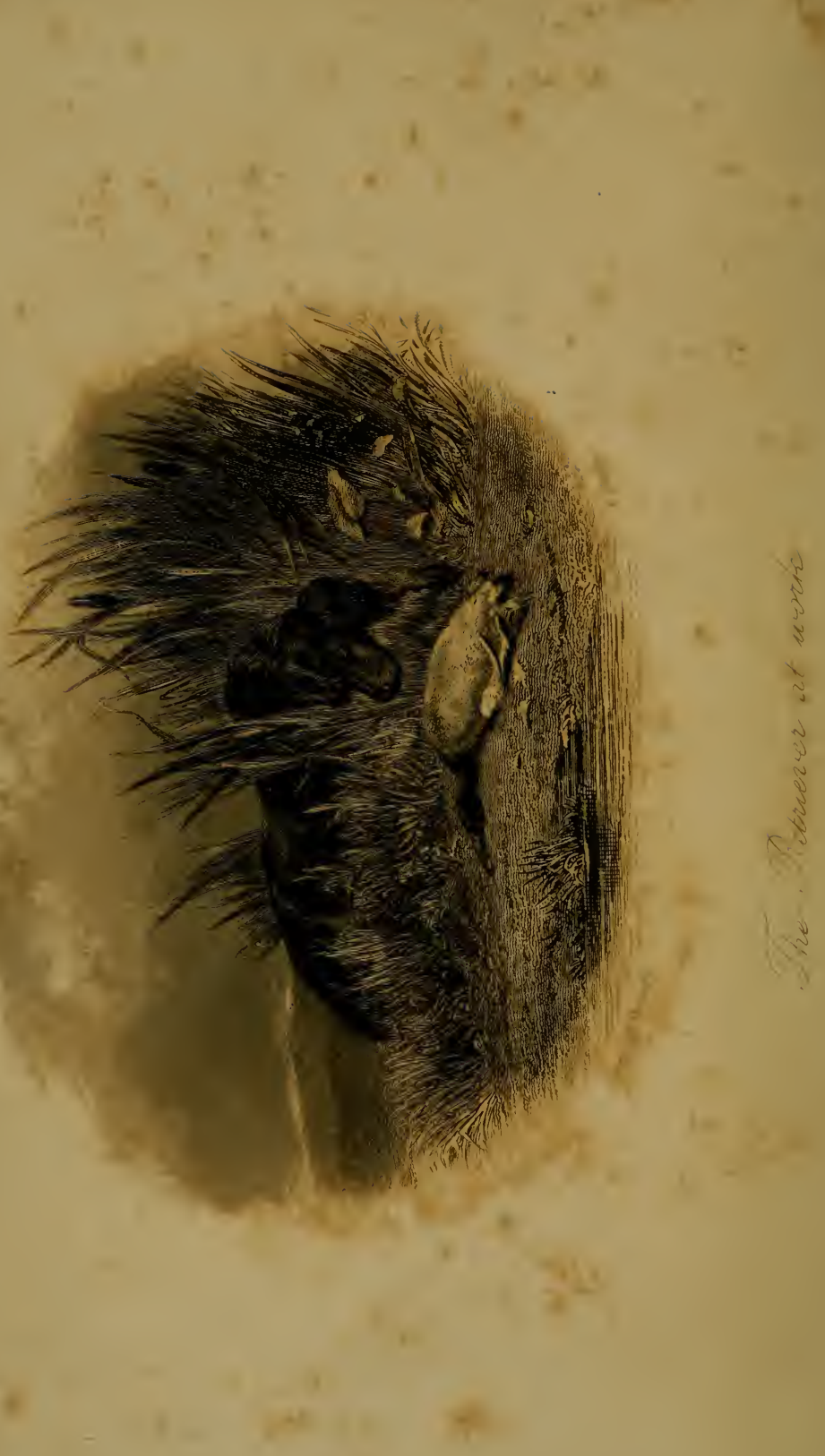




\section{THE DOG;}

AND

\section{HOW 'TO BREAK HIM:}

WITH

\section{HIS DISEASES}

AN D

M E THO D S O F C U R E.

BY

JOHN B. JOHNSON.

LONDON :

W. PIPER, BROTHERS, \& CO., PATERNOSTER ROW.

1851. 



\section{P R E F A C E.}

This little book is offered to the Public as a companion to "THE GUN; AND hOW to USE Iт." It was originally intended that the two should have formed one work: but my respected Publisher having suggested the separation of the subjects, and that each should form a separate book, I have acceded to what was, indeed, tantamount almost to a command.

As being useful for reference, an Abstract of the Game Laws is appended to this, as well 
as to the former little book; and I may safely say of both, that there is nothing set down but what results from a practical acquaintance with the subject for a quarter of a century. 


\section{THE DOG; AND HOW TO BREAK HIM.}

Ir is not irrelevant to a work like the one now offered to the notice of the public to take a retrospective glance at the subject on which it professes to treat; but any very lengthened observations on the origin or natural history of the dog, whilst they could only be repetitions of a thricetold tale, familiar even in the nursery, would be superfluous in a small book, the end and aim of which is, to give practical instructions (the result of long practice) on the best methods of breeding and training dogs for the gun, and making them perfect in the field.

It is a certain and well-ascertained fact, that all dogs found wild, and in a state independent of man, have similar characteristics; and these characteristics are, more or less, those of the shepherd's dog. It is stated by Buffon that the shepherd's dog by mere change of climate will become either "a matin, a mastiff, or a hound." Buffon 
was a closet naturalist, though a most entertaining writer; but what he advances relative to the $\operatorname{dog}$ is, to say the best of it, rather difficult to believe. Dogs taken from this country-either pointers, terriers, or hounds-to the southern states of America, degenerate in their offspring, if they breed at all; a circumstance which will account for the numbers of English dogs that are shipped from Liverpool every year to New Orleans or other southern transatlantic ports. It is as difficult to keep a dog of any value from the dogstealers in Liverpool as it is in London; but in the former place pointers, setters, spaniels, and terriers are the kinds most in demand for the American market; whilst in the latter the little things distinguished as Blenheims, or King Charles's, are what the dog-stealers of the metropolis appear most anxious to possess.

The dogs of Labrador, of Lapland, of Kamschatka, as well as those of Madagascar, and the Cape of Good Hope, and Guinea, are all similar in form; a form approaching that of a shepherd's dog, the only difference being that the dogs of the tropics are nearly destitute of hair, whilst those of the higher latitudes of the temperate and the frigid zones are clothed with the warm covering necessary to protect them from the inclemency of the climate. But none of these dogs exhibit much disposition to hunt. The wild dogs, 
indeed, hunt, being compelled to do so by hunger ; but those domesticated, or in a state of semidomestication, like the $\operatorname{dogs}$ of the towns in Turkey, seem to act the part of scavengers, and to seek their food only in the offal of the streets.

The fox, wolf, jackal, and hyena resemble the dog in their internal conformation, even to the most minute particulars; their period of gestation is the same, their food similar, but their habits widcly different, and differing from each other. The fox is a stealthy lurching animal, who obtains his prey by surprise, and, though possessed of wonderful speed and excellence of nose, never attempts, in the proper acceptation of the term, to hunt; whilst the jackal, hyena, and wolf, for the most part, act in concert and hunt in company. And in some parts of the world wild dogs - most likely sprung from a stock once domesticated-adopt the same method to secure a subsistence.

Instances are not wanting to show that dogs have run wild of late years, even in this highly cultivated country. Some years ago, a greyhound bitch, the property of Mr. Heaton, of Scarisbrick, in Lancashire, strayed from home, and for many months eluded all the attempts made for her capture or destruction; and during that period, no doubt, made dreadful havoc amongst game, as it was but too well known she did amongst the few

B 2 
sheep and lambs kept in that district. She was eventually caught, and even domesticated so far as to be taken out coursing. On these occasions she ran cunning, and seldom missed her hare. So late as the winters of 1849 and 1850 a dog, apparently wild, was seen in the fells of Eskilale, in Cumberlaud, which, it was supposed, committed great ravages amongst the sheep in that wild district. No doubt the sheep would suffer from this animal; but it was ascertained that a foxhound -a celebrated dog for trail-hunting, called "Tuner," the property of Mr. R. Copeland, of Hawthwaite Bank-was in the habit of doing a little business on his own account amongst the sheep about this time, when, naturally enough, all the mischief done in the locality would be attributed to the unknown wild dog. As an instance of the sagacity, of the almost reasoning powers of the dog, I may relate that this Tuner, when out on an errand of depredation, would acknowledge no one-not even his master. At ordinary times he was familiar with me, and was fond, as most dogs of his breed are, of being caressed, even by straugers. When on business of his own his manner was peculiar; his path was generally out of the little town of Broughton-in-Furness down to the side of the river Duddon. He would traverse the bank for some short distance, then swim the river, disappear among the coppice woods of 
Duddon bank, and thence emerge on to the fell. During his journey he would answer no call nor: whistle; he would go out of the way a score or two of yards to avoid coming in contact with a human being, and by his whole manner he appeared anxious to avoid observation, and he invariably commenced his journey towards the close of day. In an hour or two he would return and join his master at one or other of the places to which he was in the habit of resorting. The natural disposition of this dog one day got the better of his cunning: he was engaged in a trailhunt; the trail had been drawn near some sheep on a wild spot called Dunnerdale Fell; and Tuner, oll passing, supposing himself unobserved, flew upon and worried several individuals of the flock. He was destroyed in consequence.

On a shooting excursion, once, in the Isle of Man, I observed a dog, which had followed me soñe distance from a public-house, go up the side of a mountain called Greeba, and worry one of the small sheep peculiar to that island. He had passed within a yard or two of the animal, in $\mathrm{my}$ company, without attempting to molest it, and commenced his attack when he supposed himself unobserved. The sheep was his master's property, and one which he was in the habit of tending. But this is digressing from our subject.

The Newfoundland dog might be supposed, 
with every probability, to be the origin of the setter; but, then, it is a question whether the setter was not known in Britain previous to the discovery of Newfoundland. Where was the first existence of the splendid old English talbot? Utterly unknown. Whence was originally obtained the noble Irish wolf-dog? No one can tell. Who will renture to say that these are varieties of the sheep-dog? or who, hearing it so stated, will give credence to what appears so very improbable? That the pointer was first brought from Spain, the pug-dog from Holland, the Italian greyhound from the country from which it takes its name, and that the setter and spaniel are perhaps indigenous to England, and the Skye terrier to the western islands of Scotland, may be all very true. We will take for granted that it is so ; remain satisfied with the animals as they are already fashioned to our hands; and inquire no further respecting their remote ancestors, though we shall be somewhat particular relative to the immediate descent of dogs to be trained for the gun.

TRAINING DOGS FOR THE GUN.

WeLL-BRed dogs will generally require very little instruction or correction of any kind; they will set and back of their own accord at a rcry early 
age. It is not uncommon to see puppies of two or three months old point at pigeons, chickens, or other occupants of the farm-yard; and though their pointing at so early an age is from sight, and not from scent, the one naturally and invariably leads to the other.

It has often been stated that dogs which are difficult to break, and give the trainer more than ordinary trouble, are-their education being completed-better than those of a more tractable disposition; and hence it has been inferred, that cross-bred dogs, which generally possess all the bad qualities of sire and dam without any of their good ones, when thoroughly subdned, are superior to all others.

In the course of my life, I have made some experiments with these cross-bred dogs, and have succeeded, on sereral occasions, in making them obedient and tractable; but such a result has been at the expense of great trouble and vexation, the excessire correction these dogs required rendering the task of breaking them unpleasant in the highest degree. Moreorer, after their interral of rest, from February until Angust, if they did not absolutely require breaking afresh, such was their turbulent disposition, that, unless they were exercised a good deal previous to the commencement of the season, their behaviour in the field could not, for some days, be depended on. 
Even during the season, when permitted to rest for any length of time, they were apt to become wild and unruly. It need hardly be said, that having to flog a dog when out shooting is not only a most vexatious circumstance, but, in nine instances out of ten, completely fatal to diversion, by rendering the shooter unable to perform his part if the birds happen to lie-which is not often the case-or learing him no part to perform if the birds take alarm at the noise and become wild. A dog knows as well as his master when he has done wrong; and dogs which have required much flogging during their education, when they have committed themselves, are not easily caught, having a very natural repugnance to undergo the merited correction.

The great mistake in dog-breaking, and which often renders it an unpleasant and difficult task, is permitting the animals to acquire too much strength before the first lessons are inculcated. What would be thought of those professing to educate our youth did their lessons not commence until the pupils were almost full-grown? Fullgrown puppies are like full-grown men-obstinate and headstrong, and less apt, too, at profiting by instruction than those of more tender age. The teaching of dogs cannot commence too early, eren if the puppies have to be lifted over the fences. If taken amongst game occasionally at three 
months, they will, by proper management, know their business by the time they are six months old, and at that age will find more game, so long as their strength lasts, than dogs fifteen months old, whose education commenced at twelre; and they will require little or no flogging.

The first lesson in dog-breaking should be to accustom the whelps, from the time they are able to feed themselves, to the sound of the gun, particularly when their food is given to them; and this will prevent the mortification of seeing a fine young dog totally useless in the field, owing to his being frightened at the firing of a gun. At a few weeks old puppies will learn to acknowledge the report of a gim as a call to their meals, and never afterwards cause any trouble by being frightened at it in the field. When they manifest no symptoms of fear at the discharge the practice should be discontinued, as subsequently the firing of a gum or pistol has to serve a very different purpose.

As soon as whelps are able to run about they may be taken out into lanes or fields in company with an experienced old dog, and taught to come to heel when called; if they refuse, a little gentle correction, or the crack of a whip without bodily application of it, will soon reduce them to obedience. In the first instance the words "Come 
back" may be used, as well as the whistle; and in a short time the latter alone will be found sufficient. This lesson should be a daily one, when practicable, until the whistle is obeyed with alacrity. Some whelps are so timid that the sight even of the whip inspires them with too great terror, in which ease they should be taken out when hungry, and rewarded with food when called to heel, instead of being threatened with the whip. Rewarding a dog is not a method to be recommended when it can be avoided, as it has a tendency to make the dog less eager to range than when fear, and not reward, induces him to come to his master's heel, and it will make him careless of his business in pursuit of game.

When the whistle to heel is readily obeyed, as the dog is returning he should be taught to crouch, or drop, on holding up the hand and calling "Down," and compelled to remain in thit position until told to "Hold up." This lesson must be strictly enforced, it being one of the greatest importance; but it will not be difficult to teach to the whelps, provided the old dog be perfect in it, example having a wonderful effect in a dog's education. On no account suffer the whelps to move from the crouching position until desired; and by degrees compel them to drop, on holding up the hand, without being spoken to : rating a 
dog in the field, or even calling to him, is, as I have just observed, fatal to diversion: even whistling to be avoided as much as possible.

In a little while a gun or pistol should be fired, at the report of which the whelps should also be marle to drop: in the first instance by the word "Down," and the whistle, and subsequently by the report alone; they must be practised until perfect in this lesson, and there will be less trouble in making them "down charge" - a matter of almost more consequence than anything else in shooting.

If it be intended that pointers or setters shall retriere (a thing by no means to be recommended. if they are to hunt otherwise than single-handed), a rabbit-skin stuffed with hard straw intermixed with thorns, may be thrown for them to fetch. They will soon learn to do this; and the thorns inside the skin pricking the mouth upon pressure will prevent them breaking the plumage of their game when they come in contact with it.

All this should be done by the time the puppies are three or four months old; when, if the seasun will permit, they should be shown the game they are intended to pursue. But should the period of the year be adverse, they must be practised in these first lessons until such time as they can be taken out with the gun.

The most sagacious dogs are those which have 
been most in contact and company with their master. A whelp taught to "seek" a bit of bread thrown to him from the breakfast or dinner-table will sooner learn to "seek dead," and be more handy in recovering a wounded bird, than one which has not had any initiatory practice in the house.

When whelps are first taken into the fields they will most likely chase larks or other small birds eagerly; and this they may be suffered to do, as they will soon give it up on coming in contact with game : they will more readily give up chasing larks as they perceive the old dog takes no notice of them. It is almost indispensable (or at any rate it saves a deal of trouble) that an old steady dog should be taken in company with the puppies until they begin to point and hunt eagerly, when his presence is no longer beneficial.

When one dog finds game, and points it, his companions will be very apt to rush in ; and now, and not until now, is the word "Toho" to be used. It is to be introduced as a word of caution, and should never be uttered but when one at least of the dogs is upon game; nor should it be used until he is perfectly still and steady on his point. When you perceive any dog rushing in upon him who has the point, call out his name in an angry manner, hold up your hand, and make use of the word "Toho." If he has been pre- 
viously well instructed, he will be like enough to drop on your holding up the hand; and it is best if it be so, though it is sufficient if he backs the dog on the game without dropping. Howerer, should he persist in rushing up to the setting dog, the whip must be pretty freely administered. I am no advocate for excessive flogging; but when recourse is had to the whip (and it is sometimes necessary) it should be so applied that the dog will not fail to bear it in his memory.

If the birds run, the dog which first pointed them will begin to foot them; and the other dogs should now be permitted gradually to approach him and enjoy the scent, but by no means to go before or take it from him. Nothing has. a greater tendency to make a dog unruly than to suffer his companions to go up to the game before him after he has found it, and thus deprire him of his reward. When the birds run some distance, as they frequently do, by the time the first dog has gone forward a few yards the others will have got upon the scent; and should any one manifest too great eagerness he should be checked by the words "Take heedl." And it is advisable at this particular time to carry the whip in the hand. I am no adrocate for excessive flogging, as I have just observed, or for dogs which require it; but there is no harm in having the instrument of correction frequently in sight. 
When the game rises a pistol ought to be fired : the whelps ought to drop immediately at the sound of it, having been previously taught to do so ; but it is possible that they may manifest a disposition to chase, in which case "Down charge," in angry words first, and subsequently the whip must be used, until they are perfectly obedient to the words "Down charge." From this position they must on no account be suffered to move without being told.

Having got thus far, nothing more remains for the dog-breaker but to practise until the animals under his care are perfect; and to show them as much game as possible, that they may know what it is they are intended to pursue, and not take to hunting small birds. But hares will come in their way at times; and though nothing is more easy than to prevent very young dogs chasing, it becomes a difficult matter when they have acquired strength and a will of their own.

If a dog cannot be prevented from chasing hares by the application of the whip, a trash-cord to drag some fifteen to twenty yards on the groumd, with a knot at the end, so that it may check the dog when the foot is placed on it, must be resorted to. If the breaker can succeed two or three times in suddenly checking the dog when he starts to run a hare by means of this cord, and give him a jerk upon each occasion so as to throw 
him heels over head, and afterwards use the whip freely, it will most likely put a stop to the dog's chasing.

It will sometimes happen, though rarely, that a dog will persist in chasing birds on the wing after he has pointed them. In this case, when he refuses to obey the roice or the whistle, the trashcord will be found most effective; as, during the time he is pointing, the breaker can secure the cord so as to check the dog in the most effectual manner.

The trash-cord is also useful to make a dog come to heel when called, as he is easily caught by means of it when he does not evince the proper degree of obedience to the whistle or voice.

I have seen the spiked collar used to prevent dogs chasing; but am of opinion that if a dog cannot be reduced to obedience without the use of this instrument of torture, he will never be worth the trouble bestowed upon his education, and had better be parted with at once.

Breaking fence, which most young dogs are apt to do, must be carefully guarded against. The shooter should always be first orer the fence, as birds are frequently on the alert, and fly when the clogs are allowed to precede him; and thus the chances of a shot are lost. "Ware-fence," is the word to be used when rating the dog for breaking fence; and he will soon learn the mean- 
ing of the term, the more particularly if his previous lessons have been properly inculcated. Subsequently the whistle will be found sufficient.

Dogs should always be hunted up the wind, or across it. This will make them carry their heads well up, and quarter their ground better than if suffered to hunt down the wind. A good deal has been said about dogs beating a field regularly, and a great portion of what has been said is sheer nonsense. It may be a pretty sight to see dogs quarter a field with all the regularity and precision of soldiers at a review or on parade; but this allows no room for a dog's sagacity to display itself. Sagacious dogs, particularly old ones, soon acquire a better knowledge than the shooter where their game is to be found; and it is the best plan, so long as their steadiness is to be depended on, to let them have their own way, in a great measure, in this respect.

When a dog has had much practice in the field, he will, in nineteen instances out of twenty, take the wind of his own accord; but he will also, if not guarded against, be rery likely to acquire a habit of hunting round the hedge-sides on first entering a field-experience having taught him that game is most frequently found in such situations. Provided the enclosures are not large this may be permitted; but if they be of considerable extent (and small enclosures as well as fences are 
now fast disappearing) the dog will get into the way of ranging too far off. The distance, either on moor or enclosure, should never exceed a hundred to a hundred and twenty yards from the shooter. When beyond this, the whistle must be used to keep him within the proper distance.

Most shooters are aware that a dog will frequently stop in the field and look to his master for instructions. These instructions ought invariably to be conreyed by signs of the hand; eren the whistle should be used as seldom as possible; and the roice never, unless indispensably necessary.

Some dogs there are that appear to care nothing for their game when killed, and yet may be good dogs too. But it is best to let young dogs mouth the first game they see killed, and not be too eager to take it from them. If you attempt to take it away quickly it may teach the dog to break feather or tear the bird, which he will seldom do if suffered to have his own way with it for a minute or two.

When a bird is winged, or falls in a place where it cannot readily be found, the dog must be told to "seek dead." As I have previously observed, one of his earliest lessons should be to "seek" a bit of bread or anything thrown from the table; and when he comes in contact with a wounded bird he will have a pretty good idea how to go 
about his work. If a bird be winged, and seen running before the dog, it is the best plan to fire at and kill it at once; for hunting wounded birds has a natural tendency to make a dog wild. But, when this is not practicable, the dog can hardly be blamed if, when he sees a bird jumping up in a vain attempt to fly within a few yards of his nose, he rushes at it. And, if the truth be told, there are few shootcrs who, under such circumstances, are not as eager as the dog.

In the selection of names for pointers, or any (logs used with the gun, choose words of only one syllable; and let that one be such as will allow the vowel to have its most perfect intonation. Bob, Don, Rock, Moll, Fan, Di, Nell, \&c., are good names; and, where it is practicable, the names of dogs hunted together should be as dissimilar as possible in sound, in order that there may be no mistake when it becomes necessary to use the voice instead of the whistle.

THE POINTER.

WELL-BRED pointers are to be met with in most parts of the kingdom ; rarying in colour, size, \&c., as the whim or caprice of the breeder may have dictaterl. Sometimes small dogs are fashionable ; at other times large ones. I must confess I am not 
an admirer of large dogs, having found them less capable of enduring fatigue and hard work than those of a smaller size; and often, too, suffering in comparison with small dogs on the score of sagacity. The best dogs I have ever seen, and by far the best I ever possessed, hare been small; and I can safely say that I never yet met with a very large dog that could fairly lay claim eren to mediocrity in the field.

Pointers, for want of judicious crossing, are apt to become too fine and tender, and deficient in sagacity. They also frequently acquire " set ;" that is, acquire a habit of pointing at small birds or places from which the game has flown for some time, and frequently pointing at no ascertainable object whatever. A dog of this description is absolutely worthless, and may be destroyed at once; but it often happens that dogs of the most unexceptionable form acquire this habit, and it may be wished to perpetuate a breed of handsome dogs. By crossing a bitch with a largeheaded middle-sized foxhound this may be accomplished. The first remove may not be all that is desired; but the second cross from the foxhound has produced some of the best dogs ever known in the world.

It is when pointers are bred too fine, too much in-and-in, that this habit of false pointing makes its appearance; to remove which a cross with a 
distant breed of pointers may be effective, but is not so much to be depended on as having recourse to the foxhound or large harrier. It is well known that the foxhound is possessed of powers of endurance equal to those of any known dog; and these very valuable properties are frequently transmitted to his progeny in breeding with the pointer. It is fortunate when such is the case: the ne plus ultra of pointers is thus obtained.

Colonel Thornton's celebrated pointer (sold for two hundred guineas) was a direct cross from the foxhound; Captain White's dogs possess many characteristics of the same breed; and the best pointer I ever had was the second remore from a foxhound, and third from a pointer imported direct from Spain.

But, as previously stated, well-bred pointers are easily to be procured without the delay or trouble of having recourse to any cross; and if care be taken to avoid too near relationship in breeding, little apprehension need be entertained but that the produce will be in every way satisfactory.

The colour of a dog is not of much moment; but I have frequently heard and seen it stated that dark-coloured dogs have better feet than light ones-the same remark has been applied to race-horses-and I think correctly in both instances. Certainly, as far as pointers are concerned, my own experience goes to prove that 
white, or yellow and white dogs have more tender feet, and are more tender in every way, than black or brown ones. White dogs are best seen on the moors, and black ones the best in a stubble. I once had three dogs I sometimes hunted in company-a number I do not by any means recommend-they were a jet black, a perfect white, and (my old farourite) a brown and white ticked dog. The picture formed by these dogs when pointing, the white being in the middle of the three, was the most beautiful I ever beheld.

\section{THE RUSSIAN POINTER}

Is not dissimilar in appearance to a water-spaniel. By some it is called the "Russian Setter;" an appellation, in my opinion, more appropriate. These dogs never came much in my way-in fact I never saw but two in the field: one appeared a very indifferent $\operatorname{dog}$; the other a very docile, good, hard-working bitch, with excellent temper - the very opposite of the dog. I shot over this bitch repeatedly in the Isle of Man, and better I would not wish to have for cold or wet weather; but as I did not find her superior to a smooth pointer, I felt no inclination to possess a breed of dogs remarkable for their uncommon ugliness. Howerer, a friend of mine, resident in Hereford- 
shire, who had a number of the Russian dogs, gives them an excellent character; and on the strength of that recommendation I will renture to say that they will not disappoint the expectations of any sportsman who is anxious to possess something out of the common way. The dog I have noticed abore I saw under unfarourable circumstances : it was in company with one of the best pointers ever bred by Mr. R. Gill, of Richmond, Yorkshire, out of the many good ones bred by that early and respected friend.

Russian pointers are scarce; nor can I exactly say at present where the breed is to be procured, or whether the dog so called be in reality a Russian at all. Howerer, as it is my intention as soon as my other arocations will permit, to procure the best breeds possible of erery kind of sporting dog, for the purpose of sale as well as for my own pleasure, I shall not omit the Russian pointer from my catalogue.

THE SETTER.

The setter is seldom reduced to perfect obedience. Even when his education is said to be complete, and he is supposed to be perfectly trained, his naturally headstrong disposition will, after every short interval of rest, show itself in the field or on 
the mountain. To hunt in company in a satisfactory manner, he must be continually at work in all weathers, and in all seasons, or he is not to be depended on; and pointers being quite as easily procured as setters, and, moreorer, possessing superior nose, with every other quality to recommend them to the sportsman (sare, perhaps, the power of endurance) they are to be preferred; and I unhesitatingly recommend all shooters not to plague themselres with setters.

If, indeed, only one dog be kept, a setter may be tolerated; and he will, if a well-bred one, work all day and almost every day; but he will do nothing that a pointer will not do in a superior manner, sare that he will go over more ground: I am speaking of the setters of the present day.

The breed of old English setters has been for many years extinct, or nearly so. How the modern setter originated it would be somewhat difficult to say. One characteristic of the breed, be the colour what it may, is great beauty of form and action, far surpassing any of the canine race. In these the setter is pre-eminent orer his smoothcoated rival, but inferior in everything else.

THE RETRIEVER,

The Newfoundland dog, crossed with almost any 
dog of size, will produce excellent retrievers. One of the best I ever saw was the offspring of Newfoundland and mastiff. There is nothing easierthan to make a perfect retriever if you commence his lessons in time; but the business becomes more difficult if delayed until the dog is twelve months old.

A retriever should never leave the heel, unless ordered to do so; but should be kept entirely to his own business, which is to fetch a dead bird or eatch a wounded one. His hunting should never extend further than this. You may have a pointer, or a setter, or a spaniel retriever-hunting being their legitimate business; but in this case you may dispense with any other retriever altogether.

The first lesson for a young retriever may be given in company with pointer or setter pups; it is merely to be taught to keep to the heel, and drop on the firing of a gun or pistol. It must be first ascertained whether he will carry ; but little doubt need be entertained on this head, as I never yet saw any dog having a cross from the Newfoundland that did not take to carrying naturally, and as if by instinct. Sometimes it will happen, though not often, that a young dog will bite his game too hard; and this is an unfortunate circumstance. If a rabbit skin be stuffed with hard straw, with thorns intermixed, and used for him to fetch and 
carry in the first instance, it will not often happen that he will bite his game; but, should he acquire that habit, a dead bird-a pigeon, for instancemay be stuck through with sharp wires, which will prick his mouth when he attempts to squeeze too much, and may erentually cure him of a practice which will be likely to increase with age.

Of all things, avoid letting your retriever attempt to pick up a wounded crow or magpie; one of the best spaniels I ever had was completely spoiled in that way. She took to retrieving naturally, and would bring a snipe or woodcock, or any bird whatever, any distance, without breaking a feather; but, in an evil hour, I sent her in pursuit of a wounded magpie, which bit her severely; she got angry and killed the bird, and ever after flew at her game, living or dead, and bit it severely.

All dogs when urged to the pursuit of living game, such as winged birds, get angry in the chase, and are apt on these occasions to tear or mutilate that which when dead they would carry without breaking a feather. On this account, therefore, the retriever should be made to downcharge. Besides, if a dog be suffered to break away on the shot when the game is killed, he will be very apt to acquire a habit of doing the same when the game escapes; and, further, birds are frequently lost on a bad scenting day by 
orer-cagerness to secure them. A winged bird, on falling, will, if not immediately pursued, be pretty certain to run into the first bit of thick cover it can find, or eren to remain perfectly still on the spot on which it falls. Under any circumstances it is best to give the game a little time, and it will be the more easily brought to bag either by a retriever or any other kind of dog.

A retriever should be sufficiently large and powerful to carry a hare, without difficulty, at a gallop; and to jump a fence with her. There is an objection to large dogs in shooting where the corcers are thick and close; and that is, that they cannot so well makc their way through the underwood as dogs of smaller size. Both pheasants and hares are often found in coppice woods of three or four year's' growth ; and frequently in these places a luxuriant growth of brambles interposes an almost insurmountable barrier to the passage of a large dog by forming a tangled network about the height of his breast, and learing a tolerably clear. bottom, where a small dog has not much difficulty in making his way.

It is necessary that your dog should be taught to bring his game as quickly as possible and deliver it into your hand. A rather ludicrous, but at the same time rexatious circumstance occurred one day when I was shooting. I harl with 
me a rery good spaniel-one that would readily fetch birds out of the water, but would not carry them on land: I killed a bird, which fell into an old marl-pit, in the centre of which there was a small island. The dog swam to the bird, and carried it on to this island; from off which nothing could induce him to fetch it. Birds are occasionally lost in turnips or potatoes by pointer or setter retrierers dropping them out of their mouths within a few yards of the shooter' and let it be remembered that dogs will seldom notice in any way a bird thus dropped. They are aware it is not to be eaten by themselres, and their interest in it appears to cease with its capture and death.

You should teach your dog to retrieve quickly, which may be done by rewarding him with food and caressing him. But you must take care not to give him food or teach him to expect it, so as to acquire the habit of dropping his game as soon as he reaches you ; on the contrary, it will be well to let him occasionally carry a bird or hare some distance, and encourage him to do so; and to bear in mind that it should be taken from his mouth by the hand, when it is required from him, in as gentle a manner as possible.

Some $\log s$ acquire a wonderful sagacity in marking birds. An old favourite pointer, bred by myself, was remarkable in this way. It is a most useful quality, and cannot be too much encouc ? 
raged. If a retriever keeps to heel, he will, on seeing his master fire at a bird, if it does not immediately fall, soon learn to follow the bird with his eye; and in case it is supposed to be killed, he will have less difficulty in retrieving with the knowledge of the flight of the bird than if he had to depend upon the sense of smelling alone.

It is scarcely necessary to say anything about retrieving from water, as dogs bred in the way $I$ have described are invariably fond of water; nor ean any dog be entitled to the name of a retrierer unless he will take to swimming readily. I think it scarcely necessary that he should dive; though he may be taught to do this: I nerer knew an instance occur where diving was necessary. I have, indeed, seen dogs put their heads under water when hunting the moor-hen, or water-hen as it is called in some districts; but it should be distinctly understood that the proper and legitimate business of a retriever is to hunt wounded or dead, and not living game.

There are three things necessary in a retriever's education:-never to leave the heel unless ordered to do so; to remain stationary or drop on the firing of the gun; and to fetch to his master the dead or wounded game. The only difficulty is to make him down-chaige. 
THE DOG; AND HOW TO BREAK IIIM.

THE WATER SPANIEL.

THE dog passing under the name of water spaniel is covered all orer the body with soft curly hair; the curls not extending to the face, the hair upon which is short and smooth. A white stripe down the forehead and face is one of the characteristics of a breed not so often seen now as formerly; and the prevailing colour is brown, or liver colour. The water spaniel is possessed of an excellent nose, but is headstrong and unruly when encouraged to hunt-I should have said suffered to hunt; for he requires no encouragement. He takes to the water naturally, and in bygone times was a good deal used as a retriever, but has gone out of fashion since the more tractable and more sagacious Newfoundland has been introduced.

In some districts of England hunting the moorhen is a farourite diversion with the rural population; and for this pursuit the water spaniel is admirably calculated, inasmuch as he is able to bear exposure to cold and wet for a considerable time without any ill effect. I am not aware that I ever saw the mode of hunting the moor-hen described, nor will $\mathrm{I}$ waste many words on the subject. I have often assisted at the dirersion when a boy.

The moor-hen is found in ponds which are 
fringed with sedges, or cover of some description; and will, upon being disturbed, be as likely to dive as to fly. Even should it take wing its flight is nerer a long one, and is generally directed to some known pond, if there be any near. When the bird has dived, it will not attempt to $\mathrm{fly}$; indeed it is questionable whether it is able to clo so for some time after it has been under water, but will remain amongst the sedges at the side, or sometimes the middle of the water, with only its beak as far as the nostrils above the surface. The breath of the bird will of course be scented by the dogs as they are hunting amongst the sedges; but on their approach the moor-hen will dire again, and continue to do so until it is captured. Continued exertion soon tires the object of pursuit, and each succeeding time its stay beneath the surface of the water is less prolonged; and being at length too much fatigued to dive with sufficient eelerity to avoid its enemies, it is caught. The moor-hen, when cooked in a similar manner to a duck, is not a bad dish.

Hunting the moor-hen is but a tedious, slow diversion; but if the gun be called into requisition the bird is easily shot as it skims across the surface of the pond, and a few hours may be spent in a day, at the latter end of July, in this way, when no other shooting is to be had. .

In addition to being headstrong and muruly, as 
previously noticed, the water spaniel is often surly and ill-tempered, with children even; and, except for the business just described, is scarcely worth the notice of the sportsman.

THE SPANIEL， SPRINGER，OR COCKER.

SPANiels are invaluable for cover shooting; more especially so for the pursuit of the woodcock. There are sereral varieties, which have been more crossed and intermixed than any other species of the eanine race. From the fine, heary, sagacious breed belonging to the Duke of Newcastle, and known as the Clumber breed, down to the little, pug-nosed abominations called Blenheims and King Charles's, they are all bustling, active, fawning creatures. To "fawn like a spaniel" has berome a proverb.

Some spaniels are entirely mute when liming -the Clumber breed being so; others will only open upon hare or rabbit; whilst there are of the breed those that will give tongue on the quest of either woodcock or snipe, or any winged game. They will all take the water readily, and for the most fetch and carry with little tuition or trouble; the great difficulty in training spaniels being to restrain their natural ardour, and prevent them ranging too far from the gun. 
I have occasionally seen small curly spaniels in every way resembling water spaniels, except in size-with the white stripe down the forehead; in fact, water spaniels in miniature. These, I beliere, give tongue very freely; but the dogs to be recommended for all purposes should be short in the leg, long in the body, with wary (not curly) hair; the ears shorter than what is generally considered handsome, or they will eatch in the briars and be an obstruction when hunting; and they may be selected to hunt mute or otherwise, at the fancy of the sportsman. For my own part I like a spaniel to give tongue when he is certain of his game, and to open pretty freely when it rises.

In the selection of a breed of spaniels little fear need be entertained but that they will hunt: I never saw one of the breed that was not almost too eager in that way. Care should be taken to have hardy animals; and great attention should be paid to nose. The Clumber breed, and what are called Blenheims, are lemon and white; the King Charles's breed is generally supposed to be black, with tanned eyes, ears, and belly ; and from these have sprung dogs of almost all colours and every rariety of size. Amongst spaniels a cross from the terrier is not uncommon; nor have I much doubt but that such animals, when properly trained, will be most serviceable in cover. The terrier is known to possess the most exquisite 
sense of smell, is of undoubted courage and perseverance; but naturally takes to hunting rermin, hares, foxes, rabbits, \&c., in preference to game.

Spaniels should be entered at their own game, or they will cause a deal of trouble by giving tongue when they come in contact with thrushes, blackbirds, or indeed any small birds they mas find in cover. The best plan is, perhaps, to take them into a bog where there are snipes, and kill one or two as soon as possible: by doing this ther immediately acknowledge the quest of a woodcock when they come upon it. There is no better plan of training a spaniel for woodcock shooting-that bird being here only a part of the year-than to take them with a gun in pursuit of the moor-heu (as described under the preceding head of WaTEK SPANIEL). If they hunt the latter well, they will not do very wrong with the former. I am inclined to think that the scent of both birds is similar; and though the woodcock seeks a thicker corer than the moor-hen, and depends altogether on his wings for escape, and does not so obstinately keep the ground, I know from experience that training spaniels in the way I have just pointed out is the best that can be adopted. Of course it would never do to let the spaniel hunt the moor-hen without the gun. By so doing he would be taught to dodge about, and would acquire a habit of puzzling upon an old scent. When once a dog does this c 3 
-let it be pointer, setter, or spaniel-he is comparatively of no value.

The education of the spaniel should, if possible, commence in the house, yard, or garden, at a very early age, by drawing a bit of meat along the ground in a zigzag manner, and encouraging him to find it; rewarding him with food and caressing him when he has done so, but carefully preventing his eating the meat he sought for. As I have previously observed, all of the breed I erer saw have been eager to hunt; and to place an effectual check upon this ardent disposition is the great secret of training the spaniel. The puppy should be early taught to crouch at the firing of a gun ol' pistol, and compelled to remain in this position until ordered to move. It is not uncommon for young setters or young pointers to be afraid of the gun; but I nerer saw a spanicl that did not manifest symptoms of pleasure on seeing it, as well as on hearing it fired. When the purpy is obedient to the call or whistle, he may be suffered to run about in the lanes, when taken out for exercise, pretty much at his own pleasure, using the whistle when he rambles too far off. When he begins to have a notion of hunting it will be well to show him his game at once.

In shooting with spaniels the dogs are nccessarily a good deal out of sight. Even in the open ground, in turnips, their smallness of size prerents 
them being seen, and therefore they camnot well be dirceted in their motions by a wave of the hand; but it is well to teach them to obey the hand, as they will often be so placed that they can see their master whilst they are invisible to him. Most dogs, if not very unruly indeed, will stop on hearing the whistle; and if they do not forthwith come back, will look to their master to ascertain the reason they are called. At this time a wave of the hand will set them going-if not in a direction according to the shooter's wish, the whistle must be used again, and the wave of the hand, until the dogs hunt in the direction required.

It is most difficult to teach a spanicl to doun charge. It may be accomplished in the open g,round; but if a bird be flushed in corer and killed, it is ten to one but the dog sees it fall, and he will not fail to rush in to have his share of the diversion. After all, there is no great harm in this, provided the dog will retriere ; and it is undoubtedly a most certain method of bringing the game to bag.

I have just used the term, " flushed a bird in corer." Now, in sporting phraseology, the term "flushed" is only applicable to the woodcock; but this technical jargon is fast growing into disuse. The term "covey" is more frequently applied both to grouse and pheasants than the more sportsmanlike (?) term "brood." I "wisp" 
of snipe is rarely heard of; and the term "bevy" is oftener used in speaking of a bevy of girls than a bevy of quails.

Two spaniels at a time are sufficient, if the shooter be without an attendant. If a keeper be employed to hunt them, the number may be in. creased to four; but it cannot be too strongly impressed on the memory that many dogs will find most game, but are seldom conducive to the killing of it.

GENERAL OBSERVATIONS ON DOGS.

It will often be found that a dog will display a peculiar sagacity for a particular kind of work; pointers and setters will sometimes take to opening in corer, and I have had a spaniel that would point. In the latter case I was in the habit of shooting a good many landrails in the Isle of Man, and I used this spaniel in the pursuit of them. I have seen her point the landrail frequently. It is true, the point was only of sufficient duration for her to ascertain the exact position in which the bird lay, that she might make a rush upon it with certainty ; but there is little doubt that it was this instinctive pause on the part of the dog, previous to springing upon his game, that originated the idea of the setting dog. 
When pointers or setters gire tongue in corerwhich, as I hare just observed, they will sometimes acquire a habit of doing-they may serve the place of spaniels, and will find a great deal of game; but they cannot make their way through the tangled corer as spaniels will do, nor can this habit be tanght. It must come instinctirely, and may perhaps be traced to some remote cross of the foxhound or harrier. An old pointer I shot partridges orer in the year 1847 would open if he saw all the birds go away, but was mute if an individual fell. A setter I had in 1849 would not fail to give tongue upon flushing a woodeock or any winged game in cover, but was mute when a hare mored away from before him.

It is well known amongst old sportsmen that a bird pointed in a hedgerow will, whenerer it is possible, go out on the side opposite to the dog; consequently, if the hedge be a high one, the chance of a shot is lost, unless the shooter can also get to the side opposite to the dog. Sometimes this is not practicable; but, with a little practice, a sagacious dog may soon be taught to leare his point, to cross the hedgerow, and put out the bird, so that the shooter may have an unobstructed shot. The dog must be taught to do this by gently leading him away from the point to some distance, and then putting him over, or encouraging him to get orer, the hedge, 
when he will immediately proceed to the spot where he knows the bird to be. A stone may now be thrown into the hedge, and the bird put up. A dog will soon get accustomerl to this work, and will in a little time be very apt, of his own accord, to rush into the hedge from the opposite side, upon a stone being thrown in. This sort of thing is only practicable with a single $\operatorname{dog}$; and it would be destructive to a young one : it is a manœurre for a sagacious old dlog only.

One of the best dogs I ever saw, to kill game to single-handed, was a cross between a rather large wiry-haired Scotch terrier bitch and one of my own pointers; this dog, howerer, was good for nothing in company. In fact, his owner was a poacher, and I knew nothing of the existence of the dog until he came to me by chance one day, in the field, when I was shooting near his master's residence. He followed me on several subsequent oceasions. He would range well; had sagacity always to hunt with the wind in his farour; would retriere, downcharge-in fact, do everything but back (this he would not do); was nerer tired, and all weathers came alike to him. But this is a solitary instance of a dog bred in such a way being of any value-at least, I never heard of another.

A dog cannot be too much his master's com- 
panion-in doors and ont: by being thus continually together, the dog will acquire a knowledge of what is said to him, that would almost lead onc to suppose that only the faculty of speceh was wanting to enable him to reply. By being made a companion of, and kindly treated, he will the more readily perform crery task assigned to him than if he were continualy in the kennel, or taken thence to his duties in the field.

It is not well for a dog to have many masters. I rould never lend dog, horse, or gun to any one, unless I knew the party well indeed. Make this a rule, and it will save you a great deal of mortification.

A good dog will not long hunt in a satisfactory mamner for a bad shot; nor will an animal, originally well trained, long remember his lessons if he pass into the hands of an indifferent shot. It is not absolutely necessary that a doy-breaker should be a good shot; but as soon as the dog gets to know what's what, mless birds are killed to him, he will try to kill them himself. In the year 1833 , or 1834 , I was in the habit of shooting in company with a friend (a very indifferent shot) in northern Cheshire. One day we had appointed to go out, but business prereuted my so doing, and my friend, Mr. C-C-l, sallied forth with my old favourite pointer alone. On sceing him the next day, "Well, C__," said I, "what diver- 
sion?" "Oh, capital. That old dog is a famous one." "What did you kill ?" was my question. "Oh! I killed nothing with shooting; but I found a corey * * * and after I had missed three or four times, Bob caught one, and he aftcr. wards caught a lereret, and a water-hen." The fact is, master Bob would have played the same game with any indifferent shot; nor was he a solitary instance of a good dog's taking his own way with a bad marksman.

Those sportsmen who reside in the country, and have plenty of leisure time, deserve not good dogs if they do not train them themselves; such as will do this camnot hope to possess dogs of the excellence that they are capable of attaining. And to the latter class, in concluding these general observations, I unhesitatingly recommend the use of pointers, convincerl that they will be much more likely than setters to gire comparative satisfaction. In the purchase of dogs mind to have a trial, if practicable ; if not in the shooting season, take a pistol with you, and fire it when the game is found, this will show you if the dog will stand the gun. There is scarcely any remedy for a dog that has attained some age, when he is afraid of the firing of the gun. One of the finest young dogs I ever saw, and one that would find game in the most splendid style, was useless on this account; and I tried in vain the better part of a season to cure him of it, without success. 


\section{DISEASES OF DOGS.}

Geverally speaking, the first thing to be attended to, in the cure of all the diseases to which the dog is subject, is the state of the stomach; and in a naturally healthy animal, provided that important organ be kept in proper order, nature will prove the best physician.

Clean beds, well rentilated, and, at the same time, warm sleeping places, good water, and good food, of the plainest description, are prerentires of disease; whilst a deficiency of any of the essentials just enumerated is sure to bring with it a number of erils. Dogs will become costive if they are kept in confinement ; and as it is sometimes inconvenient to let them have a proper allowance of exercise, under such circumstances a teaspoonful of flowers of sulphur, or any other mild purgative, given occasionally, will be beneficial; it will make them fine in their coats, and counteract any tendency to mange. 
- Should a dog's nose at any time feel dry and warm, it may be taken for granted that the animal is, to use a phrase of the stable, amiss. In such case it will be found that his sense of smelling is rery much impaired; in fact, there is no better criterion of a dog's health than the state of his nose. If it feel cold and moist to the palm of the hand, it is more than likely that all is right; but if dry and warm, recourse should be had at once to medicine.

Dogs which run loose, which is by far the best plan when practicable, occasionally gorge themsclves with carrion; they will scent it a rery long distance, and often make a journey at night to feel upon it. There is nothing will sooner injure the olfactory organs than feeding on carrion; and it has also a tendency to produce mange, as well as other disease, by orer-heating the blood. Besides, when dogs stray at night they are sometimes away from home when their services are required, and often get into mischief, especially in a country where there are many sheep; if a dog once cats part of a dead lamb or sheep, it is a hundred to one but he takes to worrying when temptation comes in his way.

Some dogs, even pointers, are fond of going into water; and some will swim about in it for hours together. There is no harm whatercr in this so long as the weather is warm; but it is a 
habit which should be checked, as it is often productive of cril consequences in cold weather. It is useless to expect a dog to do his work properly when he is affected by cold. His nose is often filled with muens, and consequently not to be depended on ; and, instead of being moist and cool, will be found dry and harsh. On some days the scent is said to be better than others, which is no doubt perfectly true; but it should be remembered that the dog's nose may rary-a circumstance which is, for the most part, altogether orcrlooked.

With these preliminary observations, I proceed to the catalogue of canine diseases, with the methods of cure, so far as I am able to furnish them.

THE DISTEMPER.

Ox this subject I quote the following from my father. I liave seen fifty instances of the cfficacy uf the method of treatment recommended, and never knew it fail in a single one. In addition to his observations on the subject, I may remark, that youny dogs are scldom attacked with any discase except the distemper and fits. The latter are frequently caused by orer-fceding, and will become less frequent, and cease altogether when the animal is put upon proper diet and has plenty of cxecise; the former frequently terminates fatally 
if allowed to proceed beyond a certain stage, and it is therefore of the utmost importance that any altered appearance in the dog should be attended to in time, the more particularly as I have just stated that young dogs are seldom attacked by any other disease.

"The peculiar affliction of the dog, known by the name of the distemper, like the small-pox in the human species, generally makes its appearance in early life, and I scarcely ever knew an instance of a dog escaping it. The animal is very rarely afflicted with it a second time, one instance only falling under my observation during many years of extensive observation. I never knew the distemper to present itself while whelps were sucking; but from the time they quit the teat it may be expected, and will generally appear before the animal has attained his first year, often during the period between his fifth and ninth montl. On the approach of this canine scourge, the dog will be dull, his eyes will appear less bright than usual, a languidness will pervade his whole system, and his appetite will fail, or he may, perhaps, refuse his food altogether; he will be also troubled with a great degree of constipation; this is the first stage of the disease in question. The distemper makes its way by inflammation, accompanied by costiveness; and, therefore, reason clearly points out the necessity of checking the one and 
removing the other. Bleed the animal immediately, and give him a table-spoonful of syrup of buckthorn, which will most likely answer the purpose effectually; if, after the lapse of a few days the dog does not appear perfectly recovered, repeat the bleeding and the physic; a third time if found necessary, which will not often happen-not once in five hundred cases. By the process above described the disease is checked and subdued in the first instance; it cannot when thus opposed acquire strength, and is therefore easily ranquished or dissipated. Such a mode of treatment is incontestibly supported by reason, since nothing can tend so effectually to check inflammation as lowering the system. The animal should be bled very freely-in fact it is almost impossible to take too much blood from a dog under such circumstances. Supposing the subject to be a stout pointer whelp, seren or eight months old, about five ounces of blood should be taken from him. A table-spoonful of syrup of buckthorn will be found a proper dose for such an animal, and the quantity may be varied according to the age and strength of the patient.

"The operation of bleeding a dog should be thus performed:-place a cord round the animal's neck, and draw it sufficiently tight so as to throw up or elevate the jugular vein ; puncture it longitudinally (not cross-wise) with a common lancet, 
and, for the purpose of causing the blood to flow, the finger should be pressed on the rein a little below the orifice. When sufficient blood has been drawn, the puncture need not be piuned, nor any way closed, as the dog by holding down his hear draws the lips of the wound together, and the bloor forms a crust upon it immediately; hence the reason of puncturing the rein longitudinally, since, if cut cross-wise, the dog will pull the wound open every time he holds down his head, particularly in feeding.

"If the distemper be suffered to proceed beron! the first stage, the dog will be afflicted with a husky cough ; a running at the nose, and also at the eyes, will come on, attended with an offensive smell-symptoms which will continue to increase (if the animal be left to his fate) till he begins to. reel and fall; at length he becomes unable to stand, emits a most offensire efflurium, his sufferings are very severe, and he ultimately expires. from exhaustion. A dog will sometimes survire the distemper if he have not been-fed too highly, and is allowed his liberty in the homestear or. fields; under such circumstances the animal will act the part of his own physician to certain extent, by eating broad blades of grass, \&c., which operate as an emetic, and, perhaps, as a cathartic also--so kind and bountiful is nature.

"If, during the progress of the disease, the dog 
be confined, the distemper will kill him--in ninetynine cases out of a hundred, as I well know from cxperiment. If a dog be allowed to contract the distemper to a considerable extent, if he happen to survive it, cither by the aid of human assistance or otherwise, its effects will frequently be perceived afterwards in muscular twitchings or positive lamencss during, perhaps, the remainder of the animal's life.

"I am well aware that there are persons who profess or pretend to a knowledge of curing the distemper, about which they in general affect an air of mystery ; there are several reputed specifics for it also advertised : they altogether amount to nothing. The nature of the disease, and particularly its mode of approach, should constitute the first object of consideration, since it is generally and very justly admitted, that 'when a disor'der' is understood it may be considered as half cured ;' so, after what has been stated in the preceding pages on this subject, let the reader judge for himself.

"Where there are sereral young dogs, and one liappens to contract the distemper, the rest sliould be inoculated immediately, having a dose of physic administered at the same time. The disease is thus rendered much milder. A little mucus taken from the nose of the affected animal and inserted in the nostrils of the others will effectually answer 
the purpose. Vaccine inoculation has been recommended for the prevention of distemper in dogs; I tried the experiment repeatedly, but did not find it satisfactory. The distemper is highly contagious.

"When a dog has been severely affected with distemper, fits will sometimes follow. These fits will generally give way to copious renesection and physic, as already described; but should they continue, the unfortunate animal should be destroyed, or the affliction may produce that dreadful malady, canine madness, erroneously denominated hydrophobia."

FITS.

Fon the cure of fits the reader is referred to the first paragraph in the preceding article. It is necessary to keep the animal's bowels open.

THE HYDROPHOBIA.

Thrs is a dreadful disease in the human subject; but it is miscalled in the dog. In the latter there is no dread of water. I never saw but two cases in the dog, the symptoms of one of which I will endeavour to describe, though the recollection of 
the danger incurred by myself, as well as by the members of my family, makes me shudder.

In the year 1847 I had a very handsome black pointer bitch, six years old, which never had pups ; she was a great favourite, and was kept a good deal in the house; was very lively, frolicsome, good-tempered, and fawning as a spaniel. When young she had the distemper in rather a violent degree, but it left no twitching upon her; in fact, up to the period above named, the bitch was as healthy as any dog could be.

In the month of July her usual manner suddenly changed, and one of my children remarked that Di (such was her name) was unwell. This passed unnoticed by me until the next day, when my attention was again called to the circumstance. At this moment she was engaged in tearing a mat or rug placed for her to sleep upon, and I became convinced from her general appearance, and the horrid, savage glare of her eye, that she was mad. I distinctly saw her attempt to swallow pieces of her bed, though I am doubtful if she did actually swallow them. When I called her by name she answered by a racant look and the customary wagging of the tail, her under jaw drooping considerably, aud her tongue perfectly black. My first impulse was to destroy her on the spot; and, most certainly, should a similar. case ever occur to me, I should not hesitate a sin- 
gle instant. I consider it a most providential circumstance that none of my family or myself were bitten whilst she was labouring under all the symptoms of madness; and I attribute this to the fact, that the bitch was of most gentle disposition: had she been otherwise, it is more than likely that some of us would have perished by hydrophobia. I secured her to a kemnel with a chain, and she immediately commenced gnawing the sides of it so intently that she was insensible to all that was passing around her. Food was offered, and she would take it into her mouth, but could not swallow it. The previous day she seemed to have lost her sight in a great degree, and ran her head against the chairs, \&c., and she reeled and staggered like a drumken man; she now staggered about as far as her chain would permit, and, though her sight was not entirely gone, it was nearly so. She would snap at anything she happened to touch, and would occasionally attempt to break away from her chain; she was still, at times, rery intent upon gnawing the side of her kennel. She was recalled, in some measure, to consciousness by my voice; but in turning her head to whence the sound proceeded she evidently glared on vacancy. Occasionally she uttered a sharp piercing yell, as if from pain, and was in incessant involuntary-almost eonvulsire motion. The next day she grew weaker, but all the symp- 
toms just described continued, though abated in intensity. Her cyes presented the appearance of masses of ulceration, and at night, with a prolonged yell and slightly convulsive struggle, she died. On examination I found that her eyes were actually in a state of decomposition.

I am inclined to think that there is no cure for canine madness. Any attempt to administer medicine to a dog under such circumstances rould most likely be in vain, to say nothing of the rashness and extreme danger of approaching an animal when the least scratch from his teeth might be looked upon as certain death, and when he has not more than a momentary knowledge of his master, and snaps at everything that comes in his way. When labouring under this dreadful disease the dog has not the power to keep his mouth closed; but, by a convulsive effort cal close his jaws, and inflict a severe wound.

Were any dog of mine again to be attacked, I would instantly have him destroyed, howerer great a farourite he might be. Many animals have been pronounced mad which were not so in reality, which is an error on the safe side perhaps; but no one who has once noticed a real case of rabies can ever for a moment be mistaken should a second fall under his observation.

Medical skill has hitherto been unavailing to cure hydrophobia in the human subject-at least 
no well-authenticated case has ever been made public; but were I unfortunately bitten by a dog supposed to be mad, I should have recourse to speedy excision of the part, and make such appliances to the wound as would cause extensive suppuration. Many diseases may be prevented, the cure of which is more than doubtful; and such may be the case with hydrophobia.

\section{DUMB MADNESS.}

This appears to be a ridiculous term for a disease which proved fatal (in the only case which ever fell under my observation) to one of the finest young pointers ever bred, when he was eight months old.

The dog kept his mouth open; the inside of which appeared darker coloured than usual, and somewhat swelled. I bled him copiously, which produced no visible alteration. The next day all the symptoms had increased, and I observed that he was unable to swallow, though he made many attempts both to eat and drink-particularly the latter; but the water or the milk, which, by putting his nose into the vessel, he contrived to get into his mouth, uniformly ran out again; and he appeared utterly unable to pass it down his throat. He licked his fore-legs very much, and 
appeared to have a trifling discharge of saliva. All this time, however, the dog was not only sensible, but even in good spirits; and evidently experienced little pain. He died from want of food; not being able to swallow. The lungs, the liver, and indeed all those parts of the animal organization were unaffected; and they manifested not the slightest symptoms of disease. A similar remark will apply to all parts of the throat, and also to the brain. The only affection that could be discovered was in the salivary glands, which were triflingly swelled. The disorder was evidently a glandular affection, which rendered the animal incapable of swallowing sustenance. Had food been conveyed to the stomach by means of a tube, the dog might perhaps have recovered.

\section{THE YELLOWS.}

This disease is often fatal to dogs-more so than the distemper, in comparison to the number of animals attacked by it. My father, in one of his works, says it is a disease seldom met with out of the kennel. From its appearance it is not unreasonable to suppose that it bears some affinity to the jaundice in the human subject. I do not think it infectious, like the mange; and the fact 
that a number of dogs in kemuel are attacked with it at the same time, may be attributed to the prerlisposing causes being the same.

The only case which erer fell under my notice was that of a promising young pointer which hurt himself internally (as I thought at the time) by jumping from the top of a stage coach. He was attacked with the yellows, and died. I administered calomel in considerable doses, at the recommendation of a clerer veterinary surgeon, as the disease was new to me, but without effect. On the first approach of the disease the eyelids become yellow in the iuside; and the same colour extends to the belly and flanks, and eren to the whole body.

When this disease attacked the Cheshire hounds some years ago, the following was said to be an effectual mode of cure:-As soon as the log is perceived to be unwell, four grains of calomel should be given, and he should be kept warm during their operation. Then take-

Rhubarb, one ounce;

Aloes, half an ounce;

Castile soap, half an ounce :

CEthiop's mineral, half an ounce.

These should be mixed together with syrup of buckthom, and made into bolusses about the size of a nutmeg; one of which should be given every 
morning for three successive days, when one may be administered every other morning for a week, or longer if necessary.

\section{LAMENESS IN THE SHOULDER.}

This disease is produced by damp kennels, or by the dog being allowed to go too much into water. Like the rheumatism in the human subject, it may be alleviated by warmth; but is seldom perfectly cured.

\section{COLD AND COUGH}

Frequently affect the dog's sense of smelling to a considerable extent. They may be remored by administering a little mild purgative, and paring proper attention to keeping the animal warm and clean in his bed.

TO DESTROY FLEAS, ETC.

Ix summer time dogs are often much troubled with fleas and other vermin : a strong solution of tobacco will easily remore them. Dogs which sleep in brick or stone kennels are more subject 
to ticks than those whose kennels are formed of wood. In warm weather, in sheep countries, these last disgusting insects will sometimes fasten upon the shooter's legs.

FOR DOGS THAT HAVE TAKEN POISON.

Dogs are sometimes poisoned; and, too often, when such is the case, the mischief is committed wantonly and wilfully. Under such circumstances the kind of drug used is most likely unknown; and, added to this, it is seldom known how long the deadly morsel has been swallowed. If the poison can be removed from the stomach by the stomach-pump, or by causing romiting, or by any other means whatever, recovery is possible. The following will cause immediate vomiting :-

Ipecacuanha, fifteen grains ;

Water, two table-spoonsful.

To be mixed, and the dose repeated if it do not operate immediately. Then take of-

Prepared kali, three drachms;

Water, one ounce.

Give a table-spoonful every fifteen minutes to produce purging and vomiting likewise. Should the animal survive he must be fed on nourishing diet. 
FOR THE BITE OF THE ADDER, ETC.

Adpers are numerous in many of the mosses of this country, as well as in woods (particularly coppice woods), and are not uncommon on many of the grouse mountains. The adder is seldom the attacking party, but will seek his hole on being disturbed; but it sometimes happens that dogs come upon these reptiles suddenly, and a bite may be the consequence. Any kind of regetable oil applied externally and administered internally, will prevent eril consequences, if resorted to immediately; but if neglected the bite of the adder or viper may result in death. The remedy is, however, simple and unfailing; and is gencrally obtainable at any farm-house.

\section{SCAB IN THE EARS}

Often proceeds from the edges of the ears being torn by brambles, \&c., in the field; and, so long: as the dog is in work, it is not easily got rid of. It will soon disappear if the parts are well washed with warm water, and gentle purging medicine is administered internally when the animal is suffered to rest. Mercurial ointment is recommended; but is no more effective than the mode pointed out.

D 3 


\section{BURNS AND SCALDS.}

Goulard's extract of lead, two drachms ;

Water, half a pint.

Atter the third or fourth day the blisters should be opened, but the skin not remored, and dressed with the following:-

Olive oil, half an ounce;

Goulard's extract of lead, one ounce.

\section{SORE FEET.}

WASH with warm water and soap during the heat of the weather; in the more adranced period of the season salt and water.

TO BRING HAIR UPON A SCALDED PLACE.

RUB frequently with fresh hogs' lard, or any kind of animal oil.

\section{CANKER IN THE LIPS.}

RuB the affected parts with alum water two or tiree times a day; or, bole ammoniac and alum. 
FILMS IN THE EYE.

BATHE them twice a day with water in which a little vitriol has been dissolved (the size of a large horse-bean to a pint of spring water), and in a minute or two wash them with elean water.

SPRAINS.

They should be well rubbed twice a day with the following :-

Camphor, one drachm;

Brandy, one ounce.

When the camphor is dissolved add one ounce of sweet oil, and shake them well together. As sprains are attended with inflammation this should be subdued in the first place by fomenting with warm water.

TOR WOUNDS, AND TO STOP AN EFFUSION OF BLOOD.

Spirit of sal ammoniac, Opodeldoc, Sweet nitre, \} Equal parts;

Spirit of turpentine, half quantity. 
ThIs is a most troublesome and malignant disease, and is never, I think, so completely cured but that it re-appears at intervals; more especially when the animal has been fed on heating food. It will disappear, in a great degree, periodically, without medicine or external application of any kind. It is not infectious, nor is it very common. It shows itself in large red blotches along the back, on the flanks and belly, and underneath the fore legs. These blotches itch and burn to such a degree that the afflicted animal is in continual torment and agony; and as I believe the disorder, though not infectious, is communicated to the progeny of the dogs afflicted with it, I do not hesitate to recommend the destruction of the animal if the red mange has got possession of his system.

In one instance I tried everything I could think of, without success. The disease would, indeed, occasionally disappear for a time; but only to return with almost increased virulence.

A friend of mine (Mr. James Kerr, of Broughtonin-Furness) has a favourite terrier, which has been for some years subject to the red mange. In this dog the disorder frequently disappears altogether, and he appears sleek and well; whilst sometimes 
the poor thing is rolling on his back or scratching and tearing himself for hours together, in vain attempts to allay the burning torment. It is said to be curable in the following manner, but I very much doubt it :-

Train oil, one ounce;

Black sulphur, one ounce;

Liquid blister, half an ounce.

To be rubbed on the dog every other day.

Other remedies are mentioned; amongst them the following :-

Let half an ounce of corrosive sublimate be reduced in a glass mortar to an impalpable powder; to this, by a very small quantity at a time, add two ounces of spirits of wine; and, lastly, one pint of rain water ; and (with a sponge dipped in the solution) let every part affected be well washed every third day, till thrice performed : then leare three clear days, and repeat the former course of thrice, as before; letting three mercurial purging balls be given at the equal distances of three or four days.

General Hanger's celebrated receipt is a preparation of quicksilver.

I have not yet known a case where mercurial applications alone have been successful; nor, indeed, in combination with drugs of any kind. I beliere the red mange to be incurable. 
This disorder (extremely infectious) is originally produced by damp sleeping situations, dirty beds, bad food, and filth in general. It much resembles the itch in human beings, and is too well known to need particular description. Its cure is not difficult. Mix
Oil of tar, Sulphur virum,
Train oil,

Of each an cqual quantity; with which well rub the dog several times-a day elapsing between each rubbing. A little sulphur given internally will be of service. If the dog attempt to lick hinself let him be muzzled.

Mercurial ointment repeatedly applied in small quantities will effect a certain cure.

Change to diet of a cooling nature, and opening medicine, will frequently effect a cure without any external application whaterer.

The mange sometimes affects animals in a wild state-mangy foxes being frequently killer by hounds in hunting. 


\section{3}

\section{T H E G A II E L A W S.}

THE Statute I and 2 William IV. chap. 32, passed October 5th, 1831, having recited " that it is expedient to repeal the following Statutes, or so much thereof as is expedient; viz. :-

"Statute 13 of Richard II, sect. ], chap. 13, as far as it relates to persons having or keeping any greyhound, hound, or other dog, to hunt; or using ferrets, pegs, nets, harepipes, cords, or other engines, to take or destroy hares, conies, or game " Statute 22 of Edward IV. chap. 6, as far as it relates to haviug any mark or game of swans.

"Stat. 11 Hen. VII. c. $1 \%$.

"Stat. 19 Heu. VII. c. 11.

"Stat. 14 and 15 Hen. VIII. c. 10.

"Stat. 25 Hen. VIII. c. 11.

"Stat. 33 Hen. VIII. c. 6.

"Stat. 23 Eliz. c. 10.

"Stat. 2 James I. c. 27.

"Stat. 7 James I. c. 11.

"Stat. 22 and 23 Charles II. c. 25.

"Stat. 4 William and Mary, c. 23.

"Stat. 5 Anne, c. 14. 
" Stat. 9 Anne, c, 25.
" Stat. 8 Geo. I. c. 19.
" Stat. 10 Geo. II. c. 32.
" Stat. 26 Geo. II. c. 2.
" Stat. 28 Geo. II. c. 12.
" Stat. 2 Geo. III. c. 19.
" Stat. 13 Geo. III. c. 55.
" Stat. 13 Geo. III. c. 80.
" Stat. 39 Geo. III. c. 34.
" Stat. 43 Geo. III. c. 112.
" Stat. 48 Geo. III. c. 93.
" Stat. 50 Geo. III. c. 67.
" Stat. 58 Geo. III. c. 75.
" Stat. 59 Geo. III. c. 102.

"And all statutes, continuing or perpetuating any of the aforesaid statutes or parts thereof, so far as relates to the continuing or perpetuating of the same respectively."

The preamble of the Act then enacts the following provisions, in lieu of those of the repealed statutes.

The second section of the Act enacts that the word " game" shall include hares, pheasants, partridges, grouse, heath or moor game, black game, and bustards.

By sect. 3, persons killing or taking game, or using any dog, gun, net, or other engine or instrument for the purpose, on Sunday or Christmasday, shall forfeit any sum not exceeding $£ 5$; and 
persons killing or taking any partridge between February the 1st and September the 1st; or any pheasant between February the 1st and October the 1st; or any black game (except in Somerset or Devon, or in the New Forest, Southampton) between December the 10th and August 20th ; or in Somerset, Deron, or the New Forest, between December the 10th and September the 1st; or any grouse between December the 10th and August the 12th; or any bustard between March the 1st and September the 1st, shall forfeit for every head of game so killed or taken any sum not exceeding $£ 1$, with costs of conviction. And persons putting, or causing to be put, with intent to destroy or injure any game, any poison or poisonous ingredient, on any ground, whether open or enclosed, where game usually resort, or in any highway, shall forfeit any sum not exceeding $£ 10$, with costs of conviction.

Section 4 enacts that if any person, licensed to deal in game by this Act, shall buy or sell, or knowingly have in his house, or possession, or control, any bird of game after the expiration of ten days (one inclusive and the other exclusive) from the respective days in which it is unlawful to kill or take such birds of game; or if any person, not being licensed to deal in game, shall buy or sell any bird of game after the expiration of ten days (one inclusive and the other exclusive) 
from the respective days on which it is unlawful to kill or take the same, or shall knowingly hare in his house, possession, or control, any bird of game (except birds of game kept in a mew or breeding place) after the expiration of forty days (one inclusive and the other exclusive) from the respective days on which it is unlawful to kill or take the same, shall forfeit for every head of game so bought or sold, or found in his house, possession, or control, any sum not exceeding $£ l$, with costs of conviction.

But the 5th section prorides, that this Act shall not affect or alter the existing laws respecting certificates for taking or killing any game whaterer, or any woodcock, snipe, quail, or landrail, or any conies, but that such annual game certificates shall be taken out as before. And by the 23rd section, if any person shall kill or take any game, or use any dog, gun, net, or other engine or instrument, for the purpose of searching for or killing or taking game, without a certificate, he shall forfeit for every offence any sum not exceeding $\mathfrak{f J}_{5}$, with costs of conviction : and such penalty imposed by this Act shall be deemed a cumulative penalty to any penalty to which the person so convicted may be liable under any statute or statutes relating to game certificates.

By section 6, persons obtaining annual game certificates may kill and take game, liable to any 
trespass committed by them in search or pursuit of game. But no game certificate on which a less duty than $\in 4$ 0s. 10d. has been paid shall anthorize any gamekeeper to kill or take any game, or to use any dog, gun, or net, or other instrument, for the purpose of lilling or taking game, except within the limits included in his appointment as gamekeeper; but that if any such gamekeeper shall kill or take game beyond such limits, he may be proceeded against as if he had no certificate.

The ; th section provides, that in all cases where any person shall occupy any land under any lease or agreement made before the passing of this Act, except in the cases hereinafter excepted, the lessor or landiord shall have the right of entering upon such land, or of authorizing any other person or persons who shall have obtained an annual game certificate to enter upon such land for the purpose of killing or taking game thereon; and no person occupving any land under any lease or agreement, eitlier for life or for years, made previously to the passing of this Act, shall have the right to kill or take the gane on such land, except where the right of killing the game upon such land has been expressly granted or allowed to such person by such lease or agreement; or except where, upon the original granting or renewal of such lease or agecement, a fine or fines have been taken; or 
except where, in a case of a term for years, such lease or agreement has been made for a term exceeding twenty-one years.

But the 8th section provides, that nothing in this Act shall authorize any person seised or possessed of, or holding any land, to kill or take the game, or to permit any other person to do so, in any case where by deed, grant, lease, or any written or parole demise or contract, a right of entry upon such land for the purpose of killing or taking the game, has been or shall be reserved or retained by, or given or allowed to any grantor, lessor, landlord, or other person whatever; and that nothing in this Act shall defeat or diminish any reservation, exception, covenant, or agreement already contained in any private Act of Parliament, deed, or other writing, relating to the game upon any land; or in any manner prejudice the rights of any lord or owner of any forest, chase, or warren, or of any lord of any reputed manor, lordship, or royalty, or of any steward of the crown of any manor, lordship, or royalty appertaining to the king.

And the 9th section provides, that nothing in this Act shall in any way alter or affect any of the king's forest rights, or of any person entitled to any right or privilege under them, or the rights or privileges of any person holding under any grants or purchases from the crown. 
The 10th section also provides, that the Act shall not give to any owner of cattle gates, or rights of common, any interest or privilege which he did not possess before the passing of this Act; but the rights and privileges in such wastes or commons shall remain as they did before the passing of this Act.

The 12th section enacts, that where the lessor or landlord has reserved to himself the right of killing game upon any land, he may authorize other persons, haring obtained annual game cer. tificates, to pursue and kill game thereon.

But where the right of killing the game upon any land is by this Act given to any lessor or landlord, in exclusion of the right of the occupier of such land, or where such exclusive right bas been, or shall be, specially reserved by or granted to, or belongs to the lessor, landlord, or any other person than the occupier, then, if the occupier shall pursue, kill, or take any game upon such land, or give permission to any other person so to do, without the authority of the lessor, landlord, or other person having the right of killing game on such land, such occupier shall forfeit, for every head of game so killed or taken, any sum not exceeding $\mathfrak{f 2}$, with costs of conviction.-Sect. 12 .

By section 13, lords of manors, \&c., may appoint gamekeepers within the same, and authorize them to seize and take all dogs, nets, and other engines 
and instruments for the lilling or taking of game from uncertificated persons within the limits of such manors.

By section 14, lords of manors, \&c., may grant such deputations to persons acting as gamekeepers, or employed in any other capacity by other persons.

The 15th section empowers persons possessed of lands in Wales of the clear annual value of 5500 , whereof he shall be seised in fee or as of freehold, or to which he shall otherwise be beneficially entitled in his own right, to appoint gamekeepers : but the 16th section requires all appointments of gamekeepers to be registered with the clerk of the peace.

The 17th section enacts, that erery person who shall have obtained an annual game certificate may sell game to persons licensed to deal in game according to this Act; but that no gamekeeper on whose certificate a less duty than $£ 40$ s. 10 d. has been paid shall sell any game, except on the account and with the written authority of his employer; and that if he does he may be proceeded against as if he had not had a game certificate.

By the 18th section, justices of the peace sliall hold special sessions in the present year, between the 15th and the 30th days of October; and in every succeeding year in the month of July, for granting licenses to deal in game to such per'sons 
as are houseliulders or keepers of shops or stalls, - and not being innkeepers or victuallers, or liccused to sell beer by retail, or being owners, guards, or driver's of mail coaches, or other rehicles employed in the conveyance of the mails of letters, or of stage coaches, stage waggons, vans, or other public conveyances, or being carriers or ligglers, or being in the employment of any such persons; which licenses shall empower the persons to whom they are granted to buy game at any place from any person who may lawfully sell game by virtue of this Act; and also to sell the same at one house, shop, or stall only, kept by the licensed person; provided that every person, while so licensed, shall affix to some part of the outside of the front of his house, shop, or stall, and shall there keep a board having thereon his christian and surname, and the words "licensed to deal in game." Licenses granted during the present year to continue in force to July 15, 1832 ; but such as are granted in any succeeding year, to continue in force for the period of one year next after the granting. thereof. But by section 26, innkeepers and tareru-keepers may, without any license, sell game for consumption in their own houses, such game having been procured from some person licensed. to deal in game by virtue of this Act. And, by section 21, persons being in partnership, and carrying on their business at one house, shop, or 
stall only require but one license. Licenses become void on conviction of any offence against this Act.-Sect. 22.

Persons licensed to deal in game under this Act must annually, and during the continuance of their license, obtain a certificate on payment of a duty of $£ 2$ to the collector or collectors of the assessed taxes, from whom they shall receive a receipt on payment of one shilling; which receipt they shall get exchanged for a certificate under this Act, in like manner as receipts for the duty in respect of killing game are exchanged for game certificates; and if any person obtaining a license under this Act shall purchase or sell, or otherwise deal in game as a licensed dealer, before he shall obtain a certificate in exchange for such receipt, he shall, for every offence, forfeit $£ 20$.

The collectors are to make out lists of persons who have obtained licenses to deal in game, and are to produce the same to all persons making application at seasonable hours to inspect them, on payment of one shilling.-Sect. 20 .

By sect. 25, if any person not having obtained a game certificate (except such person be licensed to deal in game according to this Act) shall sell, or offer for sale, any game to any person whatever; or if any person authorized to sell game under this Act shall sell, or offer for sale, any game to any person whatever, except a person 
licensed to deal in game, he shall forfeit for every head of game so sold, or offered for sale, any sum not exceeding $£ 2$, with costs of conviction.

And if any person, not being licensed to deal in game according to this Act, shall buy any game from any person whatever, except from a person licensed to deal in game according to this Act, or bona fide from a person affixing to the outside of the front of his house, shop, or stall, a board purporting to be the board of a person licensed to deal in game, he shall for every head of game so bought forfeit any sum not exceeding $£ 5$, with costs of conviction.-Sect. 27 .

And if any person, being licensed to deal in game according to this Act, shall buy or obtain any game from any person not authorized to sell game for want of a game certificate, or for want of a license to deal in game; or if any person, being licensed to deal in game according to this Act, sell, or offer for sale, any game at his house, shop, or stall, without such board as aforesaid being affixed to some part of the outside of the front of such house, shop, or stall, at the time of such selling or offering for sale; or shall affix, or cause to be affixed, such board to more than one house, shop, or stall, or shall sell any game at any place other than his house, shop, or stall, where such board shall have been affixed; or if any person not being licensed to deal in game according 
to this Act shall assume or pretend, by affixing such board, or by exhibiting any certificate, or by any other device or pretence, to lie a persoil licensed to deal in game, he shall, for erery offence, forfeit $£ 10$, with costs. (Sert. 28.) But the buying and selling of game by persons employed on the behalf of any licensed dealer in game, and acting in the usual course of his employment, and upon the premises where such deating is carried on, is a lawful buying and selling in cases where the same would have been lawful if transacted by the licensed dealer himself. And licensed dealers may sell any game sent to them to be sold on account of other licensed dealers. (Sect. 29.)

The 30th sect. reciting, that, as after the commencement of this Act game will become an article which may be legally bought and sold, and that it is therefore just and reasonable to provide that summary means should be provided for protecting it from trespassers, enacts, that any per son committing trespasses, by entering or being in the daytime upon any land, in search or pursuit of game, woodcocks, \&c., shall forfeit any sum not exceeding $£ 2$, with costs of conviction; and that if any persons, to the number of five or more together, commit any trespass, by entering in the daytime upon any land in search of game, \&c., each of them forfeit not less than $£ \tilde{z}$, with costs of 
conviction ; the leave and license of the occupier of the land so trespassed upon shall not be a sufficient defence in any case where the landlord, lessor, or other person shall have the right of killing game upon such land by virtue of any reservation or otherwise; but that such landlord, \&c., shall, for the purpose of prosecuting for each of such two offences, be deemed to be the legal occupier of the land; and that the lord or steward of the crown of any manor, lordship, or royalty, shall be deemed to be the legal occupier of the land of the wastes or commons within such manor, lorlship, \&c.

The 31 st sect. enacts, that if any person shall be found on any land, or upon any of the crowu forests, parks, chases, or warrens in the daytime, in search or pursuit of game, or woodcocks, snipes, quails, landrails, or conies, any person having the right of killing the game upon such land, by virtue of anv reservation or otherwise as is provided for by this Act, or the occupier of the land (whether there shall or shall not be any such right by reservation or otherwise), or any gamekeeper or servant of either of them, or any person authorized by either of them, or for the warden, ranger, verderer, under-keeper, or other officer of such forest, \&c., may require the person so found forthwith to quit the land whereon he shall be so found, and also to tell his name and 
place of abode; and if such person, after being so required, refuse to tell his real name and place of abode; or if he give a description of his place of abode of so general a nature as to be illusory, for the purpose of discovery, the party so requiring his address, or any person acting by his order and in his aid, may apprehend him, and convey him, as soon as conveniently may be, before a magistrate; and the offender (whether so apprehended or not) shall forfeit any sum not exceeding $£ 5$, with costs of conviction. But no person so apprehended shall, on any pretence whatever, be detained for a longer period than twelve hours from the time of his apprehension until brought before a magistrate; and if he cannot, on account of the absence or distance of the residence of the magistrate, or on account of any other reason. able cause, be brought before a magistrate within such twelve hours, then he shall be discharged; but may, nevertheless, be proceeded against for the offence by summons or warrant, according to the provisions hereinafter mentioned, as if no apprehension had taken place.

By the 32nd sect., if any persons, to the num. ber of five or more together, shall be found upon any land, or in any of the crown forests, parks, chases, or warrens, in the daytime, in search or pursuit of game, or woodcocks, snipes, quails, lanảrails, or conies, any of them being armed with 
a gum, and any of them by violence, intimidation, or menace, preventing, or endeavouring to prevent, any person authorized, as hereinbefore melltioned, from approaching them for the purpose of requiring them, or any of them, to quit the land whereon they shall be so found, or to tell their or his name and place of abode; erery person so offending, and every person then and there aiding or abetting such offender, shall forfeit for every offence any sum nut exceeding $£ 5$, with costs of conviction; which penalty shall be in addition to, aud independent of, any other penalty to which any such person shall be liable for any offence against this Act.

And by sect. 39, if any person commit any trespass by entering or being, in the daytime, upon any crown forests, parks, chases, or warrens, in search or pursuit of game, without being first duly authorized, he forfeits any sum not exceeding $£ 2$, with costs of conviction.

But the 35th sect. enacts that the aforesaid provisions against trespassers and persons found on any land shall not extend to any person hunting or coursing upon any lands with hounds or greyhounds, and being in fresh pursuit of any deer, hare, or fox, already started upon any other land; nor to any person bona fide claiming, and exercising any right or reputed right of free warren or free chase, nor to any gamekeeper lawfully ap- 
pointed within the limits of any free warren or frec chase ; nor to any lord or any steward of the crown of any manor, lordship, or royalty; nor to any gamekeeper lawfully appointed by such lord or steward within the limits of any manor, \&c.

The 36 th sect. enacts, that when any person shall be found, by day or by night, upon any land, or in any of the crown forests, parks, chases, or warrens, in search or pursuit of game, and then and there having in his possession any game which shall appear to have been recently killed, any person having a right of killing the game upon such land, by virtue of any reservation or otherwise, as before provided for, or the occupier of the land (whether there shall or shall not be such right by reservation or otherwise), or any gamekeeper or servant of either of them, or any officer, as aforesaid, of any forest, \&c., or any person acting by the order and in aid of any of the said several persons, may demand from the persons so found the game which may be in his possession; and in case he shall not immediately deliver up the same, may seize and take it from him, for the use of the person entitled to it.

The 34th sect. defines what shall be deemed daytime for the purposes of the Act, namely, from the beginning of the last hour before sunrise to the expiration of the first hour after sunset.

The 24:th sect. provides, that if any person not 
having the right of killing game upon any land, nor having permission from the person having the right, wilfully take out of the nest or destroy in the nest upon the land the eggs of any bird of game, or of any swan, wild-duck, teal, or widgeon, or knowingly have in his house, shop, possession, or control, any eggs so taken, he shall forfeit for every egg so taken or destroyed, or found in his possession, any sum not exceeding 5 s., with costs of conviction.

The remaining sections of the Act (viz., from 37 to 47 inclusive) provide fur the application of the penalties for offences against the Act, the time of the payment thereof, and the periods of imprisonment for non-payment; the form of conviction; the power of summoning witnesses; the time for proceedings, and the mode of enforcing appearance; the appeal, and the venue and proceedings. The 46 th section provides, that the Act shall not preclude actions for trespass; but that, where any proceedings have been instituted under this Act in respect of any trespass, no action at law shall be maintainable for the same trespass. And the 48th section, that the Act shall not extend to Scotland or Ireland.

From the great injury caused to tenant farmers on some estates by the over-preservation of hares, the Legislature has deemed it advisable to sanction their being destroyed by occupiers much 
on the same terms long previously permitted in reference to rabbits. For this purpose a measure was framed, and passed on the 22nd of July, 1848, 11 and 12 of Vic., c. 29, entitled "An Act to enable Persons having a Right to kill Hares in England and Wales, to do so by themselves, or persons authorized by them, without being required to take out a Game Certificate." Though not altogether bearing on the gun, it still is sufficiently so to warrant a summary of its provisions here.

The statute commences by declaring that, from the damage which has been, and is continually done, by hares to the produce of inclosed lands, and the great losses that have thereby accrued, and do accrue, to the occilpiers of such lands, it is expedient that persons in the actual occupation of these lands, or the owners thereof who have the right of killing game thereon, should be allowed to take, kill, and destroy hares without the obtaining of an annual game certificate, or the payment of any duties of assessed taxes which might otherwise be incurred by the use of dog, gun, net, or other engine for that purpose. The Act provides, accordingly, that any persons in actual occupation of inclosed lands, or any owner thereof who has the right of killing game thereon, or any person directly authorized by him in writing according to the form annexed, shall not, for killing hares, be 
liable to any of the penalties in force by divers laws referring to the duties on game certificates, or by other taxes bearing upon the agents used in killing game. Special mention is made of

$$
\begin{aligned}
& 48 \text { George III., c. } 55 \text {, } \\
& \text { 52 George III., c. } 93 \text {, } \\
& 3 \text { and } 4 \text { Victoria, c. } 17 \text {; }
\end{aligned}
$$

in all of which penalties consequent on not taking out a game certificate, or taxes incurred by the use of dog, gun, and net, are repealed, as far as the killing of hares only is concerned, according to the conditions already stated, or more amplified in following sections.

The second section of the Act limits the authority from owner or occupier to one person only, at the same time in one parish, and further enacts that a copy of this authority shall be sent to the Clerk of the Petty Sessions, who shall enter it in a register provided for that purpose; this notice holding good from the time of its date to the lst of February following, when fresh serrice will be required. Should, however, the authority be reroked, it is necessary for the owner or occupier so recalling it to send at once notice of such permission being withdrawn to the Clerk of the Petty Sessions.

The following is the form of authority required :- 
I., A. B., do authorize C. D. to kill hares on [" $\mathrm{my}$ lands," or "the lands occupied by me," as the case may be] within the of [here insert name of the parish or other place, as the case may be]. Dated this day of [here insert the day, month, and year].
(Witness,)
A. B.

Section the third enacts that persons so authorized to kill hares shall not be liable to any duties of assessed taxes as ganc-keepers, unless otherwise chargeable.

By section four the privilege of killing hares without a certificate is extended to coursing them with greyhounds, or hunting them with beagles or other hounds. This exemption reaching to all persons joining in the pursuit of them by these means.

Section the fifth protects hares from the laying of poison for their destruction, and from the use of fire-arms or gun of any description by night.

Section six-"the weak place" in the Actsuffers this privilege to be got over by private agreement between landlord and tenant, who may so, "now and hereafter," bind, and be bound ; any agreement not to take, kill, or destroy any game upon any lands, debarring the tenant from either 
himself or by deputy killing hares as otherwise provided by the Act.

The eight section confines the operation of the measure to England and Wales only, while sections nine and ten are occupied with the usual technical detail of terms, \&c.

THE END. 





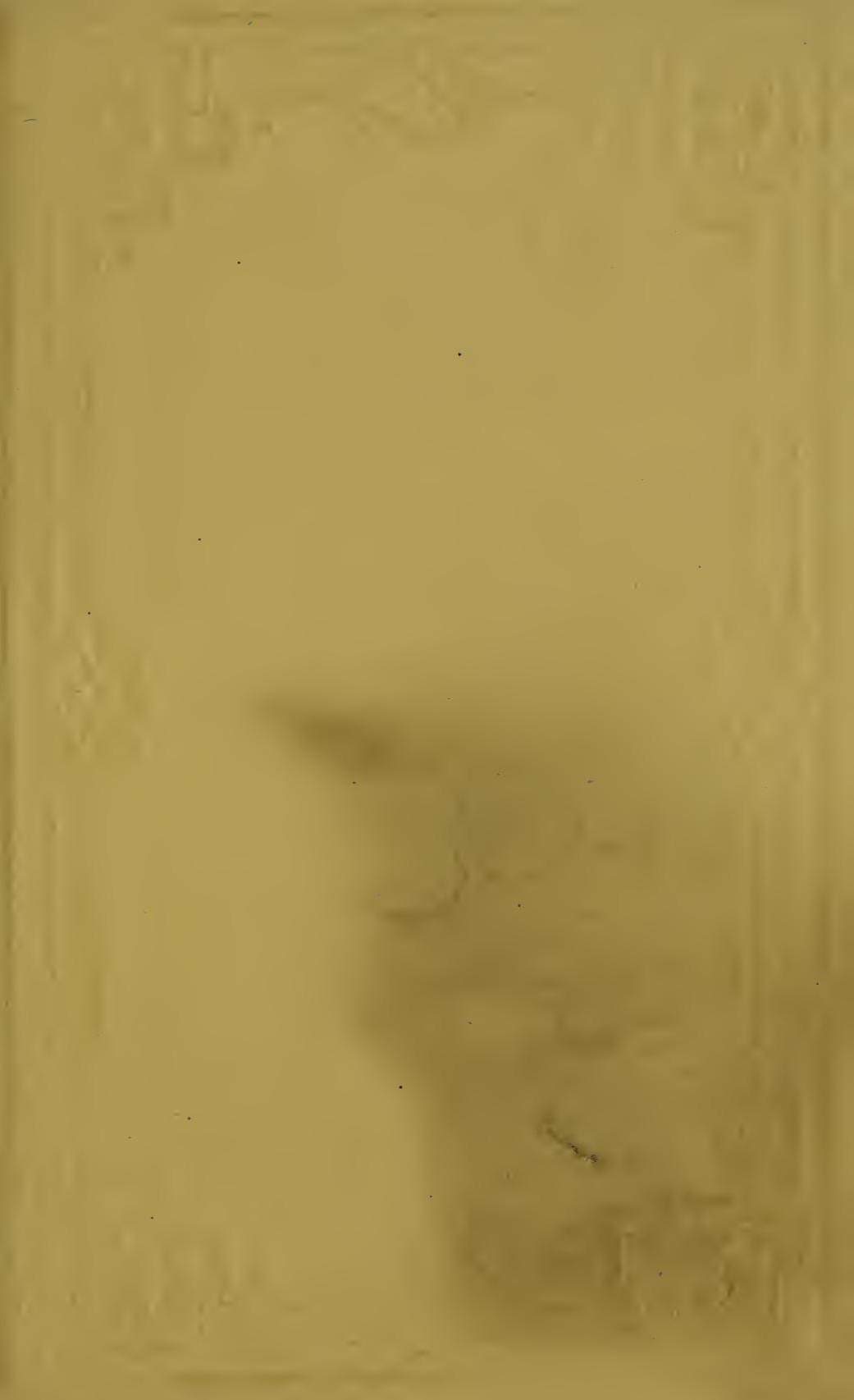




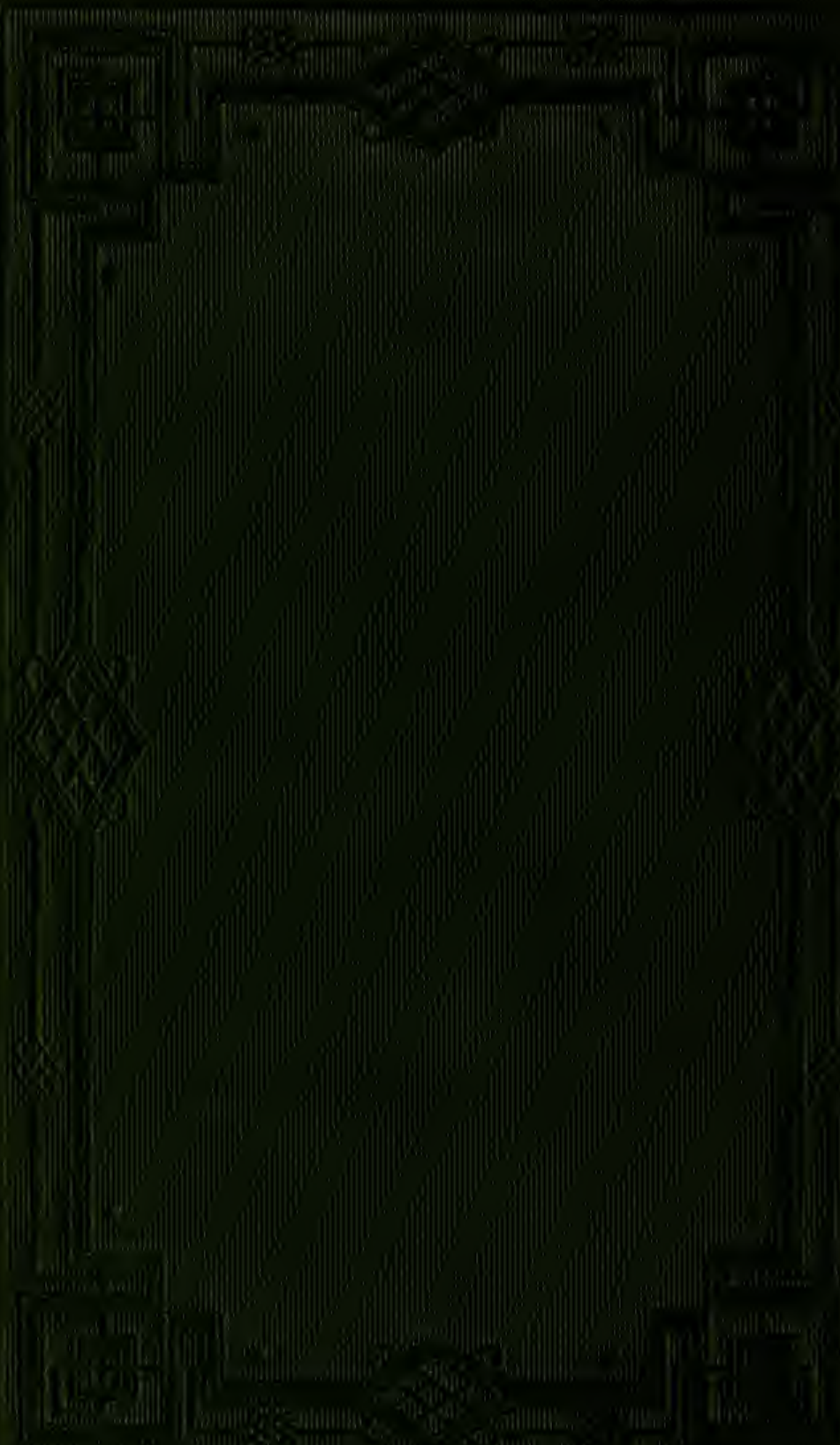

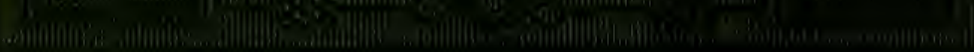

